Lancelot, J. R. 1975: Les systèmes uranium-plomb chronomètres et traceurs de l'évolution des roches terrestres. Thesis I.P.G., Paris, 280 pp.

Phillips, W. E. A., Stillman, C. J., Friderichsen, J. D. \& Jemelin, L. 1973: Preliminary results of mapping in the western gneiss and schist zone around Vestfjord and inner Gåsefjord, south-west Scoresby Sund. Rapp. Grønlands geol. Unders. 58, 17-32.

Pidgeon, R. T. \& Johnson, M. R. W. 1974: A comparison of zircon U-Pb and whole rock Rb-Sr systems in three phases of the Carn Chuinneag granite, northern Scotland, Earth Planet, Sci. Lett. 24, 105-112.

Reineck, H. E. \& Singh, I. B. 1973: Depositional sedimentary environments. New York: Springer Verlag, 439 pp.

Steiger, R. H. \& Henriksen, N. 1972: The geochronology of the Scoresby Sund area. Progress report 3: zircon ages. Rapp. Grønlands geol: Unders. 48, 109-114.

Wegmann, E. 1935: Zur Deutung der Migmatite, Geol. Rdsch. 26, 305-350.

Centre Geophysique et Geologique, Université des Sciences Montpellier,

9 Rue Pouget, Montpellier, 34000 France.

\title{
Sedimentological observations in middle and late Triassic rocks, Jameson Land Basin, central East Greenland
}

\section{Lars B. Clemmensen and Frank Andreasen}

The middle and late Triassic rocks of Jameson Land and the nearby part of the Scoresby Land area in central East Greenland (fig. 33) were studied during the 1975 field season as part of a $21 / 2$-year joint GGU-University of Copenhagen project. The work entailed the detailed measurement of several sedimentological sections. Emphasis was laid on the primary sedimentary structures and a large number of palaeocurrent measurements were carried out. The ultimate goal of this approach is to understand the palaeogeographical evolution of the sedimentary basin during middle and late Triassic time.

This note is a preliminary account and delineates only the sedimentary history of the basin in very broad terms.

\section{Stratigraphy}

The studied sedimentary sequence belongs to the middle and late Triassic Gipsdalen and Fleming Fjord Formations (Perch-Nielsen et al., 1972, 1974) and to the overlying Kap Stewart Formation of Rhaetic-Liassic age (Surlyk et al., 1973). The Gipsdalen Formation consists of the basal Solfaldsdal Member and the overlying Kap Seaforth Member; the Fleming Fjord Formation is composed from base upwards of the Edderfugledal Member, the 
Fig. 33. Location of measured Triassic sections in the Jameson Land Basin, central East Greenland.

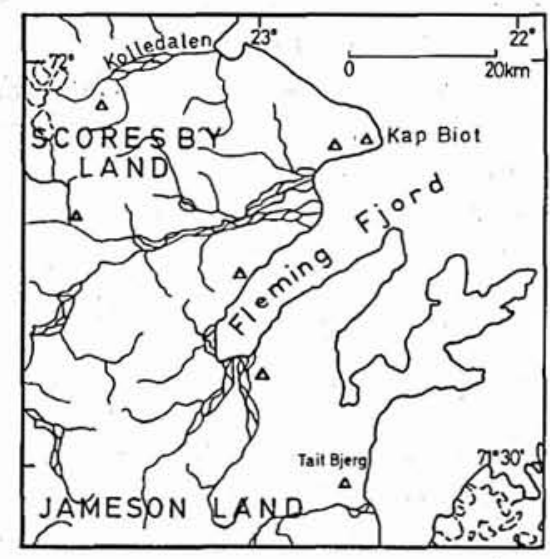

Malmros Klint Member and the Ørsted Dal Member (Perch-Nielsen et al., 1974). New data collected during the summer suggest a further subdivision of the Fleming Fjord Formation. Detailed measurements of the Edderfugledal Member have made it clear that this unit is always composed of two characteristic and easily recognisable sub-units, a lower yellowish orange sub-unit dominated by dolomitic mudstones and an upper variegated sub-unit where quartz sandstones and mudstones of different types prevail. The greyish red mudstones of the Malmros Klint Member appear very uniform throughout the studied area, whereas the Ørsted Dal Member consists of a lower variegated sandstone-mudstone unit overlain by a light-coloured limestone unit. Any stratigraphical revision will, however, await further field work.

\section{Sedimentary facies and depositional environment}

Within the stratigraphical framework of Perch-Nielsen et al. (1974) it has been possible to establish several characteristic sedimentary facies based on the physical, chemical and biogenic features of the rocks. The main facies of each stratigraphic unit will be briefly described in ascending order.

\section{Gipsdalen Formation}

This formation is locally more than $200 \mathrm{~m}$ thick. Although it has been studied in detail only at a few localities it is now clear that a greater variety of facies types make up the formation than previously thought.

Solfaldsdal Member. In the Kolledalen region the majority of the sediments are composed of giant-scale cross-bedded, weakly gypsiferous, light sandstones interbedded with more silty, generally structureless, reddish sandstones. In the Fleming Fjord area variegated gypsumbearing beds and reddish silty sandstones displaying both current-ripples and wave-ripples make up the sequence together with limestones, sandstones and dark mudstones (the 
'Myalina Limestone' of Grasmück \& Trümpy, 1969). The Myalina beds are among others characterised by interfering wave-ripple systems, capped-off wave-ripples, double-crested wave-ripples and mud-cracks.

The bulk of the sequence in the Kolledalen area is of aeolian origin whereas the red-beds towards the south-east were deposited in a shallow-water environment that often dried out and occasionally became evaporitic. The 'Myalina Limestone' display a wealth of sedimentary structures indicative of very shallow water and frequent subaerial exposure. The content of bivalves (Myalina), gastropods and conchostracans points towards a marine origin for the Myalina beds according to Grasmück \& Trümpy (1969).

Kap Seaforth Member. This member is generally composed of variegated gypsiferous mudstones and sandstones, the latter locally displaying large-scale cross-bedding. Halite crystal casts are abundant in the mudstones. The sequence displays a distinct cyclic pattern.

It is suggested that the mudstones were deposited in a very shallow lake. In dry periods the lake shrank, aeolian sand was spread over the area and gypsum became concentrated in the exposed sediments by evaporative pumping.

\section{Fleming Fjord Formation}

This formation is well-exposed, through often inaccessible, in cliffs and reaches $400 \mathrm{~m}$ thickness. Detailed sections have been measured at seven localities (fig. 33), especially in the lowermost member.

Edderfugledal Member. Two distinct facies association can be distinguished within this member. One facies association, confined to the lower half of the member, commonly consists of closely interbedded wavy and lenticular laminated dolomitic mudstones, horizontally laminated siliceous mudstones, stromatolites and algal limestone breccias. The second facies association is typically composed of thick wave-rippled sandstones, reddish sandy siltstones, siliceous mudstones, dolomitic sandstones and mudstones, thin stromatolites and algal limestone breccias. It is laterally very persistent. Thus, one $5 \mathrm{~cm}$ thick stromatolite horizon could be traced for more than $45 \mathrm{~km}$ in a N-S direction (fig. 34).

The sediments are thought to delineate a shallow lake or bay subject to frequent exposure and characterised by varying salinity and shore-line oscillations.

Malmros Klint Member. This member was subjected to a detailed study and the following facies could be distinguished:

(1) Lenticular bedded, fine or coarse siltstone

(2) Generally structureless coarse silt or fine sandstone

(3) Wave- or current-rippled, often muddy sandstone

(4) Strongly bioturbated lenticular bedded muddy sandstone

(5) Large-scale cross-bedded sandstone

(6) Mud-flake conglomerate

All facies display intensive mud-cracking. Bioturbations are absent from the major part of the member. Thin calcareous horizons are frequent. 

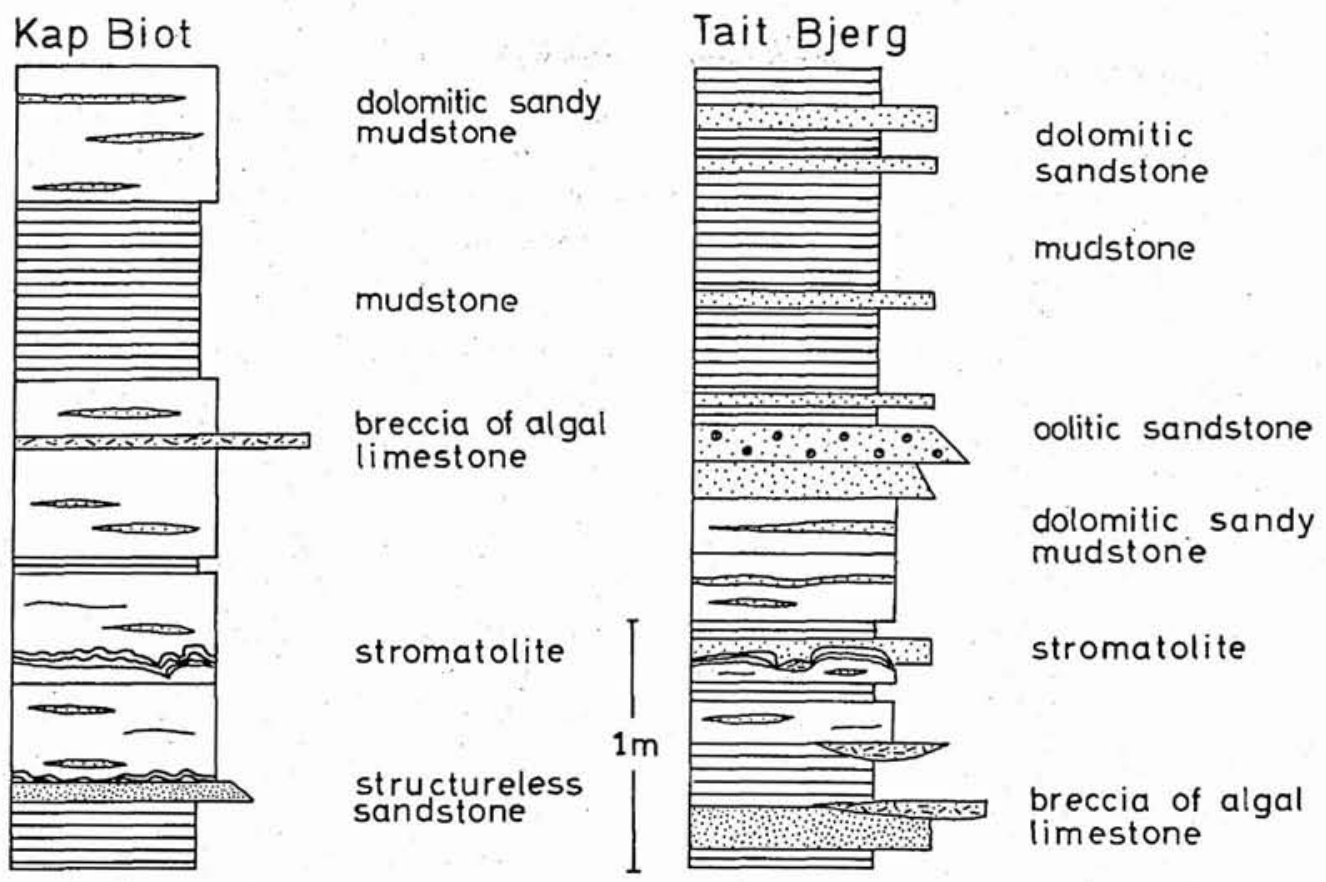

Fig. 34. Graphic logs showing some of the facies types in the upper part of the Edderfugledal Member, Jameson Land. The illustrated sediments form the upper part of a sedimentary cycle initiated by light sandstones and red mudstones.

The sedimentary aspects of the member suggest deposition in a huge featureless lake or bay during a warm and rather dry climate. The material was brought in mainly during rainstorm flooding from the surrounding wadi fans. In intervening periods desiccation was intense.

Ørsted Dal Member. This member is composed of two distinctly different lithological rock units. Overlying the red mudstones of the Malmros Klint Member follows a sequence of variegated mudstones and light cross-bedded sandstones. Mud-cracks are abundant. The sandstones generally become thicker and coarser towards the top of the member. The sandstones are often bioturbated. The variegated sequence is overlain by bitumen-rich shales and limestones the latter often mud-cracked. The limestones wedge out towards the north-west where the sandstones of the underlying unit become very coarse-grained and pebbly.

The variegated mudstones and sandstones were probably deposited on a prograding flood-plain. The limestones are described as marine by Grasmück \& Trümpy (1969) because of the content of bivalves and ostracods. The occurrence of mud-cracks, however, points towards very shallow conditions of deposition, perhaps in a lagoon or a lake. The climate was probably characterised by alternating dry and wet seasons. 


\section{Kap Stewart Formation}

This formation is generally poorly exposed for sedimentological studies and only two good sections were encountered. The sediments in question consist of thick sequences of black thinly laminated mudstones, flaser laminated silty sandstone, large-scale cross-bedded often pebbly sandstone, horizontally laminated sandstones, and wave-rippled sandstones. Both fining-upwards and coarsening-upwards sequences occur. Marine(?) trace fossils and bivalves appear locally. Palaeocurrent measurements of foresets gave a bipolar orientation with the strongest mode towards the south.

The depositional environment for this formation is believed to be a tidally influenced delta. The climate during deposition of the Kap Stewart Formation was humid and contrasts to the overall dry climate prevailing during deposition of the Gipsdalen and Fleming Fjord Formations.

\section{References}

Grasmück, K. \& Trümpy, R. 1969: Notes on Triassic stratigraphy and paleontology of north-eastern Jameson Land (East Greenland). Meddr Grønland 168,2, 134 pp.

Perch-Nielsen, K., Birkenmajer, K., Birkelund, T. \& Aellen, M., 1974: Revision of Triassic stratigraphy of the Scoresby Land and Jameson Land region, East Greenland. Bull. Grønlands geol. Unders. 109, (also Meddr Gronland 193,6), $51 \mathrm{pp}$.

Perch-Nielsen, K., Bromley, R. G., Birkenmajer, K. \& Aellen, M. 1972: Field observations in Palaeozoic and Mesozoic sediments of Scoresby Land and northern Jameson Land. Rapp. Grønlands geol. Unders. 48, 39-59.

Surlyk, F., Callomon, J. H., Bromley, R. G. \& Birkelund, T., 1973: Stratigraphy of the Jurassic-Lower Cretaceous sediments of Jameson Land, East Greenland. Bull. Grønlands geol. Unders. 105, (also Meddr Grønland 193,5), 76 pp.

Mineralogisk Museum, Øster Voldgade 5-7, 1350 København $K$.

\section{Uranium exploration in northern East Greenland}

\section{Agnete Steenfelt}

The uranium prospecting programme between $72^{\circ}$ and $76^{\circ} \mathrm{N}$ which commenced in 1973 (Nielsen \& Larsen, 1974: Nielsen \& Steenfelt, 1975) was continued in 1975 from GGU's base at Stordal in Hudson Land. The programme included detailed geological and radiometric investigations in areas of high radioavtivity as well as geochemical sampling.

\section{Geological and radiometric work}

Previous work, mainly airborne gamma spectrometry and regional geochemical sampling, indicated that the acid extrusive rocks of Devonian age are important source rocks for 